\title{
Transcriptional and translational analysis of subsequent infection with Staphylococcus aureus and Proteus mirabilis in Caenorhabditis elegans
}

\author{
Udayakumar Prithika*, Gnanasekaran JebaMercy, Krishnaswamy Balamurugan \\ From 2nd International Science Symposium on HIV and Infectious Diseases (HIV SCIENCE 2014) \\ Chennai, India. 30 January - 1 February 2014
}

\section{Background}

Caenorhabditis elegans can be effectively used to study the dynamics of polymicrobial infections. Proteus mirabilis as an opportunistic pathogen does not cause death in C. elegans. Hence, in the present study, the C. elegans was pre infected with the pathogen Staphylococcus aureus to make the C. elegans immuno compromised to study the effect of $P$. mirabilis in the host.

\section{Methods}

This study involved in investigation of impact of subsequent infections at physiological, transcriptional and translational levels using C. elegans.

\section{Results}

Physiological status of C. elegans was analyzed using killing assay, CFU count and CLSM analysis. The mRNA expression analysis indicated the regulation of host specific immune regulatory genes, CUB like proteins (F08G5.6), neuropeptide like factors (nlp-29) and C type lectin genes (clec-60 and clec-87) during subsequent infections. To study which protein is regulated against subsequent infections, SDS-PAGE analysis was performed using the proteins extracted from C. elegans exposed with subsequently infected samples for different time intervals. Results of 1D electrophoresis clearly suggested that subsequently infected samples showed significantly more differentially regulated proteins compared to their respective controls.

\section{Conclusion}

The physiological assays and molecular studies demonstrated the vulnerability of a host as an integral event

* Correspondence: prithikaudayakumar@gmail.com

Department of Biotechnology, Alagappa University, Science Campus, Karaikudi-630004, India during $S$. aureus infections that enables the bacteria to suppress the host immune system, which subsequently lead to the opportunistic pathogen $P$. mirabilis to exert its pathogenicity in a host system. Further studies are needed to check the translational status of the host during subsequent infections.

Published: 27 May 2014

doi:10.1186/1471-2334-14-S3-P7

Cite this article as: Prithika et al:: Transcriptional and translational analysis of subsequent infection with Staphylococcus aureus and Proteus mirabilis in Caenorhabditis elegans. BMC Infectious Diseases 2014 14(Suppl 3):P7.

Submit your next manuscript to BioMed Central and take full advantage of:

- Convenient online submission

- Thorough peer review

- No space constraints or color figure charges

- Immediate publication on acceptance

- Inclusion in PubMed, CAS, Scopus and Google Scholar

- Research which is freely available for redistribution 